\title{
Drying characteristics and physical properties of medicinal and edible mushrooms
}

\author{
Bo-Min Kim ${ }^{1}$, Eun-sun Jung ${ }^{1}$, Yong-hyun Aan ${ }^{1}$, In-Wook Hwang ${ }^{3}$, \\ Shin-Kyo Chung ${ }^{1,2 *}$ \\ ${ }^{1}$ School of Food Science and Biotechnology, Kyungpook National University, Daegu 41566, Korea \\ ${ }^{2}$ Food and Bio-Industry Research Institute, Kyungpook National University, Daegu 41566, Korea \\ ${ }^{3}$ Department of Food Science and Nutrition, Dong-A University, Busan 49315, Korea
}

\section{약용버섯과 식용버섯의 건조방법에 따른 품질특성}

\author{
김보민 ${ }^{1} \cdot$ 정은선 ${ }^{1} \cdot$ 안용현 ${ }^{1} \cdot$ 황인욱 $^{3} \cdot$ 정신교 ${ }^{1,2 *}$ \\ ${ }^{1}$ 경북대학교 식품공학부, ${ }^{2}$ 경북대학교 식품생물산업연구소, ${ }^{3}$ 동아대학교 식품영양학과
}

\begin{abstract}
In this study, the drying characteristics of medicinal (Ganoderma lucidum, Phellinus linteus) and edible (Pleurotus eryngii, Lentinus edodes) mushrooms were investigated. Their shrinkage ratios, Hunter's color values, and rehydration ratios were evaluated. Mushrooms were cut with rectangular $(1 \mathrm{~cm})$ and square $(1 \times 1 \mathrm{~cm})$ shapes, and dried in the room temperature and at $50^{\circ} \mathrm{C}$ and $70^{\circ} \mathrm{C}$ using hot-air dryer. Initial moisture contents of edible mushrooms were higher than those of medicinal mushrooms, whereas final moisture contents were vice versa. Drying rate was the highest when drying at $70^{\circ} \mathrm{C}(\mathbf{p}<\mathbf{0 . 0 5})$. Moreover the drying rate of square slices was higher than that of rectangular slices $(\mathbf{p}<\mathbf{0 . 0 5})$. The shrinkage ratios of both medicinal mushrooms and edible mushrooms were the least when drying at $50^{\circ} \mathrm{C}$ and $70^{\circ} \mathrm{C}$, respectively $(p<0.05)$. The changes of color values were less in the medicinal mushrooms dried in the room temperature than in the hot-air dried medicinal mushrooms $(p<0.05)$. However, in case of edible mushrooms, the changes of color values were less in the hot-air dried mushrooms $(p<0.05)$. Rehydration ratios of medicinal mushrooms dried at $50^{\circ} \mathrm{C}$ was the highest $(p<0.05)$. In contrast, rehydration ratios of edible mushrooms was the highest when drying in the room temperature $(p<0.05)$. Thus, the hot-air drying at $50^{\circ} \mathrm{C}$ would be suggested as the efficient drying method for both medicinal mushrooms and edible mushrooms.
\end{abstract}

Key words : drying characteristics, mushrooms, shrinkage ratios, Hunter's color values, rehydration ratios

\section{서 론}

최근 건강에 대한 국민의 관심이 증대됨에 따라 자연식 품, 저칼로리식품 또는 유기농식품을 선호하려는 경향이 높아지고 있으며, 이러한 욕구를 충족시켜 주는 식품중의 하나로 버섯류를 들 수 있다. 버섯은 분류학적으로 대부분

*Corresponding author. E-mail : kchung@knu.ac.kr Phone : 82-53-950-5778, Fax : 82-53-950-6772

Received 28 April 2016; Revised 20 July 2016; Accepted 4 August 2016.

Copyright (c) The Korean Society of Food Preservation. All rights reserved.
담자균류와 자낭균류에 속하는 고등균류이며(1) 풍미가 뛰 어나고 탄수화물 및 단백질, 지질, 무기질, 비타민 미네랄 등의 각종 영양소를 다양하게 함유하고 있다(2). 최근에는 항종양활성 및 항암활성, 면역증강, 산화억제 작용, 혈당감 소, 혈중 $\mathrm{HDL}-$ 콜레스테롤 증가 등의 효과가 밝혀지면서 건강기능식품의 소재로 많이 이용되고 있다(3-5). 우리나라 에는 약 1,150 여종의 버섯이 자생하고 있으며, 그 중 330여 종이 식용 및 약용버섯으로 사용되고 있다. 식용버섯에는 새송이버섯, 표고버섯, 팽이버섯, 송이버섯 등이 있으며, 영지버섯, 상황버섯, 차가버섯, 동충하초, 천마 등은 약용버 섯으로 분류된다(6). 그러나 생체 버섯은 조직이 단단하지 못하며 호흡작용이 활발하고 수분함량은 높기 때문에 유통 
기간은 품종에 따라 다소 차이는 있지만 상온에서 대략 2 3일이면 품질의 저하 및 갈변이 발생하게 된다(7). 버섯 표면의 갈변은 소비자가 구매를 결정하는 주요한 지표이다 (8).

버섯의 장기저장 및 유통을 위해서 건조가 필수적이며, 버섯의 건조 방법에는 일반적으로 자연건조와 열풍건조가 이용된다 $(9,10)$. 제어가 쉬운 열풍건조는 장기저장을 위한 건조 방법으로 가장 많이 사용되어진다. 그러나 열풍건조 는 초기단계의 건조에서는 매우 실용적이지만 건조가 진행 됨에 따라 건조 효율이 떨어지기 때문에 많은 에너지가 필요할 뿐 아니라 색상악화 및 구조변형을 발생시키는 단점 을 가지기도 한다(11). 이러한 건조를 통해 부패 미생물의 성장방지, 효소 작용 저해, 수분에 의해 발생할 수 있는 다양한 반응들을 최소화 할 수 있다(12). 버섯의 건조에 관한 연구로는 표고버섯과 상황버섯의 열풍건조 특성 $(8,13)$, 건조방법에 따른 양송이버섯의 물리적 특성 및 흡습 특성(14), 능이버섯의 건조과정 중 물성 변화(15)를 비롯하 여 건조버섯의 항암 및 항산화 효과에 관한 연구(6) 등이 있다.

본 연구에서는 버섯의 수확 후 효율적인 전처리 가공을 위하여 약용버섯(영지버섯, 상황버섯)과 식용버섯(새송이 버섯, 표고버섯)의 절단 및 건조방법, 온도에 따른 건조특성 을 조사하고 건조버섯의 색도 및 수축률, 재수화성을 평가 하여 보고하는 바이다.

\section{재료 및 방법}

\section{실험 재료}

본 실험에 사용된 영지버섯(Ganoderma lucidum)은 경상 북도 칠곡군 소재, 상황버섯(Phellinus linteus)은 경상북도 안동시 임하면 소재의 버섯 농장에서 2015년 7월중에 수확 된 것을 구입하여 냉장보관 $\left(4^{\circ} \mathrm{C}\right)$ 하면서 시료로 사용하였다. 새송이버섯(Pleurotus eryngii)과 표고버섯(Lentinus edodes) 은 대구시 소재의 대형마트에서 구입하여 시료로 사용하였 다.

\section{건조 방법}

버섯의 건조 시료는 버섯 갓 부위를 가로로 $1 \mathrm{~cm}$ 폭으로 절단(장방형 절편, slice 1)하거나, 가로 및 세로 각각 $1 \mathrm{~cm}$ 로 절단(정방형 절편, slice 2)하여 사용하였다. 자연건조는 실 험실 $\left(25 \pm 2^{\circ} \mathrm{C}\right.$, 상대습도 $\left.60 \sim 65 \%\right)$ 에서 건조하였으며 열풍건 조는 열풍건조기(CCDO-05, Cleanthermo, Gyeonggi-do, Korea)를 이용하여 $50^{\circ} \mathrm{C}$ 와 $70^{\circ} \mathrm{C}$ 에서 각각 건조하였다. 건조 시료의 중량은 자연건조는 12 시간 까지는 1 시간, 이후에는 3 시간, 열풍건조는 1 시간 간격으로 분석용 전자저울 (LE244S, Sartorius, Germany)로 측정하였다. 최종 건조시간
은 건조시료의 중량변화가 $\pm 1 \%$ 범위에 이를 때까지로 하였 다. 건조버섯의 건조 조건별 최종수분함량은 Table 1 과 같 으며, 각각 영지버섯은 7.32 15.68\%, 상황버섯 9.70 18.55\%, 새송이버섯 $0.96 \sim 1.98 \%$, 표고버섯 $1.95 ~ 2.47 \%$ 이었다.

Table 1. The final moisture contents of the dried medicinal and edible mushrooms

(unit: \%)

\begin{tabular}{ccccccc}
\hline & \multicolumn{5}{c}{ moisture content } \\
\cline { 2 - 7 } sample $^{1)}$ & \multicolumn{2}{c}{$\mathrm{ND}^{2)}$} & \multicolumn{2}{c}{ HD50 } & \multicolumn{2}{c}{$\mathrm{HD} 70$} \\
\cline { 2 - 7 } & $\mathrm{S1}^{3)}$ & $\mathrm{S} 2$ & $\mathrm{~S} 1$ & $\mathrm{~S} 2$ & $\mathrm{~S} 1$ & $\mathrm{~S} 2$ \\
\hline $\mathrm{GL}$ & $15.68 \pm 1.34^{\text {ad) }}$ & $12.80 \pm 0.58^{\mathrm{b}}$ & $8.55 \pm 1.13^{\mathrm{c}}$ & $8.79 \pm 0.51^{\text {cd }}$ & $7.32 \pm 0.98^{\mathrm{e}}$ & $7.88 \pm 1.19^{\mathrm{de}}$ \\
$\mathrm{PL}$ & $18.55 \pm 0.67^{\mathrm{a}}$ & $16.53 \pm 0.70^{\mathrm{b}}$ & $13.59 \pm 0.29^{\mathrm{c}}$ & $12.56 \pm 0.41^{\mathrm{c}}$ & $10.94 \pm 1.21^{\mathrm{d}}$ & $9.70 \pm 0.64^{\mathrm{e}}$ \\
$\mathrm{PE}$ & $1.98 \pm 0.18^{\mathrm{a}}$ & $1.96 \pm 0.46^{\mathrm{a}}$ & $1.12 \pm 0.22^{\mathrm{b}}$ & $1.92 \pm 0.46^{\mathrm{a}}$ & $0.96 \pm 0.41^{\mathrm{b}}$ & $1.43 \pm 0.38^{\mathrm{ab}}$ \\
$\mathrm{LE}$ & $2.19 \pm 0.62^{\mathrm{a}}$ & $2.29 \pm 0.20^{\mathrm{a}}$ & $2.20 \pm 0.72^{\mathrm{a}}$ & $1.95 \pm 0.30^{\mathrm{a}}$ & $2.39 \pm 0.45^{\mathrm{a}}$ & $2.47 \pm 0.28^{\mathrm{a}}$ \\
\hline
\end{tabular}

${ }^{1)} \mathrm{GL}$, Ganoderma lucidum, PL, Phellinus linteus, $\mathrm{PE}$, Pleurotus eryngii, LE, Lentinus edodes.

${ }^{2)} \mathrm{ND}$, natural drying; $\mathrm{HD} 50$, hot-air drying at $50^{\circ} \mathrm{C}$; $\mathrm{H} 70$, hot-air drying at $70^{\circ} \mathrm{C}$. ${ }^{3} \mathrm{~S} 1$, rectangular shape slice $(1 \mathrm{~cm})$; S2, square shape slice $(1 \times 1 \mathrm{~cm})$.

4)a-e means with different letters within the row are significantly different $(p<0.05)$.

수분 함량

수분함량은 $\mathrm{AOAC}$ 법(16)에 의거하여 $105^{\circ} \mathrm{C}$ 상압가열건 조법으로 측정하였다.

\section{건조 특성 곡선}

건조시간에 따른 약용 및 식용버섯의 수분함량은 건조시 간별로 측정한 버섯 시료 중량에서 각 버섯의 초기수분함량 을 이용하여 환산하였다. 건조특성곡선은 건조시간에 대한 각 버섯의 수분함량의 변화를 도시하여 나타내었다.

\section{수축률}

수축률은 건조가 끝난 버섯 시료의 단경을 dial caliper (Alltrade, Long beach, CA, USA)로 측정하여 건조 전후의 길이차이를 백분율 $(\%)$ 로 나타내었다.

\section{색도 측정}

버섯 시료의 건조 전후의 표면을 표준 백색판 $(\mathrm{L}=97.79$, $\mathrm{a}=-0.38, \mathrm{~b}=2.05)$ 으로 보정된 Hunter 색차계 $(\mathrm{CM}-700 \mathrm{~d}$, Minolta Co., Osaka, Japan)를 이용하여 명도(L, lightness) 및 적색도(a, redness), 황색도(b, yellowness) 값을 30회 반복 측정하여 평균값 \pm 표준편차로 나타내었다. $\Delta \mathrm{E}$ 는 건조 전 버섯과 건조 후 버섯의 색차 값에서 아래의 식으로 구하였 다.

$\Delta \mathrm{E} \quad \Delta(-L)^{2}+\Delta\left(a_{0}-a\right)^{2}+\Delta\left(b_{0}-b\right)^{2}$

$\mathrm{L}_{0}, \mathrm{a}_{0}, \mathrm{~b}_{0}$ : 건조 전 시료

$\mathrm{L}, \mathrm{a}, \mathrm{b}$ : 건조 후 시료 


\section{재수화율}

재수화율은 Jeong 등(17)의 방법으로 건조버섯 $3 \mathrm{~g}$ 을 증 류수 $\left(100 \mathrm{~mL}, 20^{\circ} \mathrm{C}\right)$ 에 2 시간 동안 침지한 다음, 표면수를 여지로 제거하고 중량을 측정하여, 침지 전후의 중량 차이 를 건조시료 중량에 대한 백분율(\%)로 구하였다.

\section{통계분석}

통계처리는 SAS 프로그램(Statistic Analysis System, v9.4 SAS Institute Inc., Cary, NC, USA)을 이용하였다. 모든 실험 은 3회 반복이상 실시하여 결과를 평균값 \pm 표준편차로 나타 내었고, Duncan의 다중검정법으로 유의성을 검증하였다 $(\mathrm{p}<0.05)$.

\section{결과 및 고찰}

\section{약용 및 식용버섯의 자연건조 및 열풍건조특성}

약용버섯인 영지버섯, 상황버섯과 식용버섯인 새송이버 섯, 표고버섯의 초기 수분함량은 각각 $65.63 \%, 70.06 \%$, $90.12 \%, 84.40 \%$ 로 약용버섯보다 식용버섯이 더 높은 수분
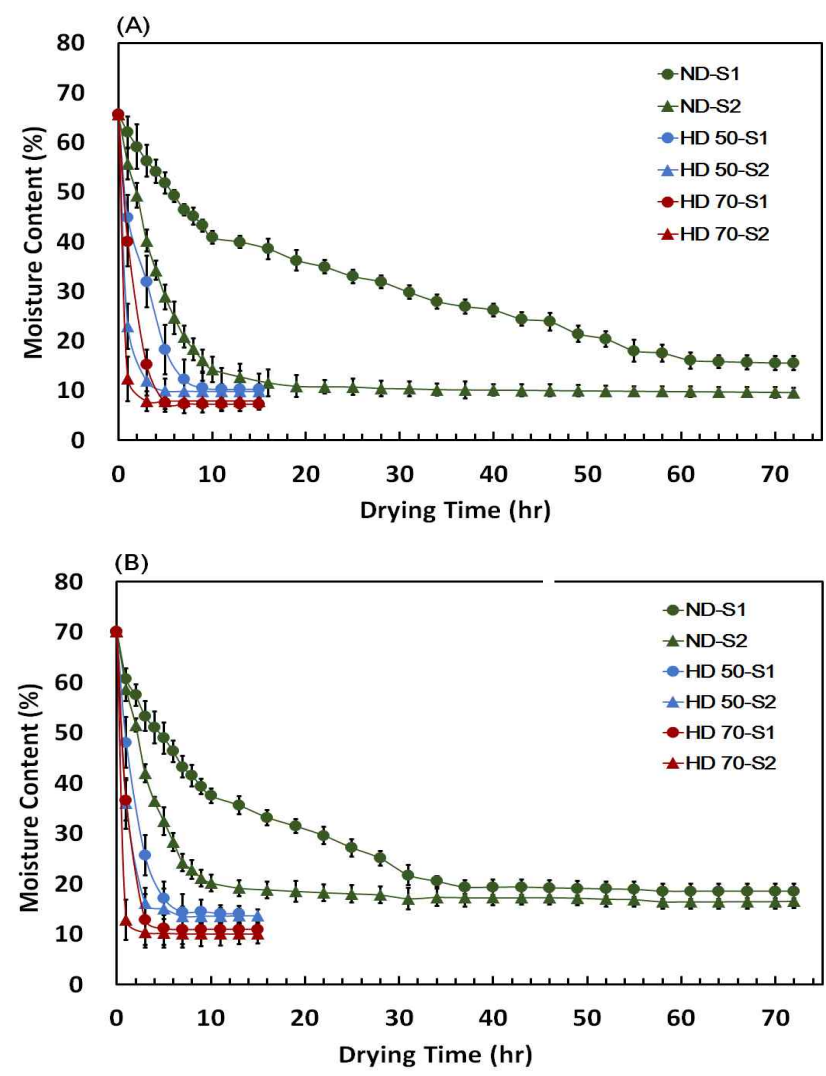

Fig. 1. Moisture content of medicinal mushrooms depending on the drying conditions.

(A), Ganoderma lucidum, (B), Phellinus linteus.

ND-S1, natural drying of slice 1; ND-S2, natural drying of slice 2; HD50-S1, hot-air drying of slice 1 at $50^{\circ} \mathrm{C}$; HD50-S2, hot-air drying of slice 2 at $50^{\circ} \mathrm{C} ; \mathrm{HD} 70-\mathrm{S} 1$, hot-air drying of slice 1 at $70^{\circ} \mathrm{C}$; HD70-S2, hot-air drying of slice 2 at $70^{\circ} \mathrm{C}$.
함량을 보였다 $(18,19)$. 약용버섯과 식용버섯을 장방형 및 정방형으로 절단하여 중량의 변화가 없을 때 $( \pm 1 \%)$ 까지 자 연건조와 열풍건조 $\left(50^{\circ} \mathrm{C}, 70^{\circ} \mathrm{C}\right)$ 하여 측정한 최종수분함량 을 Table 1 에 나타내었다. 약용버섯의 최종수분함량은 자연 건조구에 비하여 열풍건조구가 낮았으나 식용버섯은 그다 지 큰 차이가 없었으며, 절단 형태에 따라서도 각 버섯의 최종수분함량은 크게 차이가 나지 않았다. 이들 버섯의 장 방형 및 정방형절편의 자연건조 및 열풍건조특성곡선을 Fig. 1과 2에 나타내었다. 버섯과 같이 수분함량이 높은 식물성 식품의 건조특성곡선은 표면의 수분이 증발과 내부 수분의 표면 이동 속도가 일정한 건조 초기의 항율건조기와 건조가 진행되면서 표면의 왜곡과 경화현상으로 내부 수분 의 확산속도가 감소하여 건조 속도가 줄어드는 감율건조기 로 구분된다. 약용버섯 및 식용버섯 절편은 자연건조구가 열풍건조구에 비하여 항율건조기가 비교적 길었으며, 정방 형절편이 장방형절편에 비하여 항율건조기가 길고 건조속 도도 빨랐다. 또한 $70^{\circ} \mathrm{C}$ 열풍건조구가 $50^{\circ} \mathrm{C}$ 열풍건조구에 비하여 항율 및 감율건조기간이 모두 짧아 건조가 비교적 단시간에 진행되었다. Krokida 등(20)은 버섯을 포함한 여 러 가지 채소류의 건조 실험에서 건조온도의 영향이 상대습
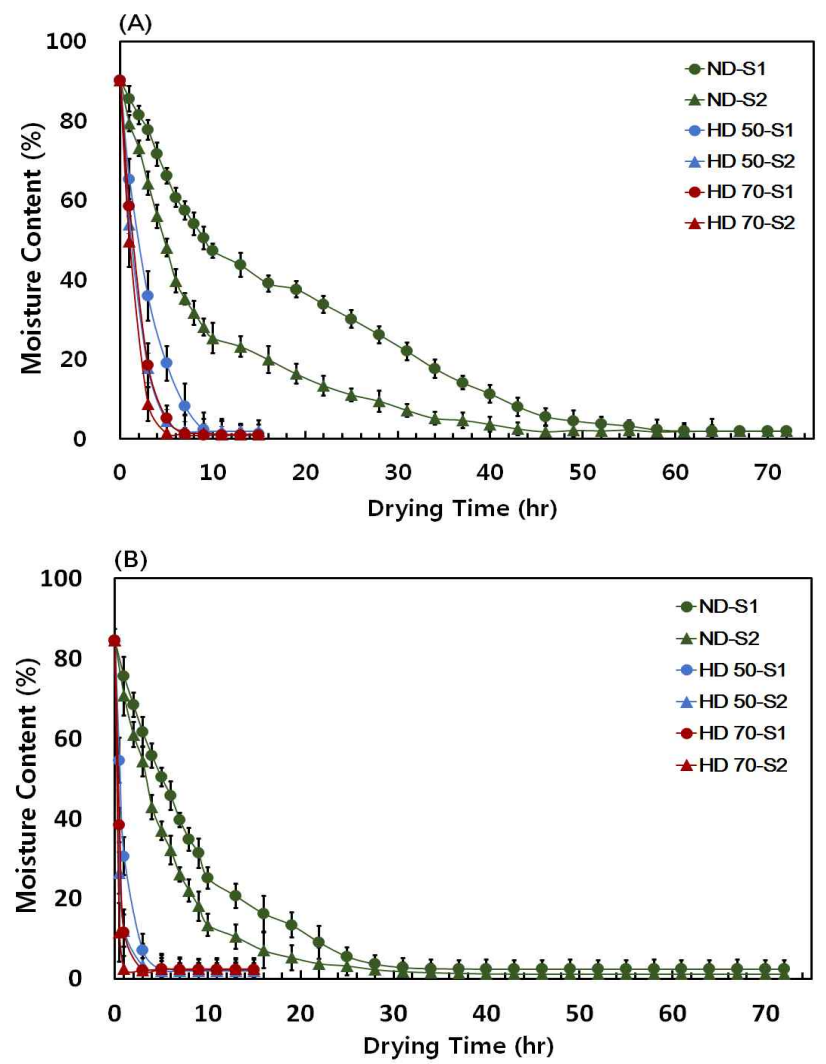

Fig. 2. Moisture content of the edible mushrooms depending on the drying conditions.

(A), Pleurotus eryngï, (B), Lentinus edodes.

ND-S1, natural drying of slice 1; ND-S2, natural drying of slice 2; HD50-S1, hot-air drying of slice 1 at $50^{\circ} \mathrm{C}$; HD50-S2, hot-air drying of slice 2 at $50^{\circ} \mathrm{C}$; HD70-S1, hot-air drying of slice 1 at $70^{\circ} \mathrm{C}$; HD70-S2, hot-air drying of slice 2 at $70^{\circ} \mathrm{C}$. 
도와 풍속보다 크다고 보고하였다. 한편, 모든 건조 구에서 장방형절편 보다 정방형절편의 건조 시간이 짧았는데, 이 는 정방형절편이 장방형절편에 비하여 건조가 진행되는 표면이 고르고 표면적이 넓어서 내부 수분의 이동과 이의 표면에서의 증발이 신속하게 일어난 것(11)으로 사료된다. 건조시간이 길어져도 영지버섯은 수분함량이 $7.32 ~ 15.68 \%$, 상황버섯은 9.70 18.55\% 이하로는 건조가 진행되지 않았 으나, 식용버섯인 새송이버섯과 표고버섯은 각각 수분함량 이 0.96 1.98\%, 1.95 2.47\% 까지 감소하는 것으로 나타났 다(Table 1). 이는 상황버섯과 영지버섯은 목질버섯으로 조 직이 단단하고 치밀하기 때문에 감율 건조기에 들어서면서 내부 수분의 확산과 이동이 식용버섯에 비하여 진행되기 어렵기 때문이다. Yoo 등(21)은 아가리쿠스버섯을 고온에 서 건조 하였을 때 갓 부위에 비해 조직이 치밀한 대 부위에 서 건조속도가 늦으며 최종수분함량이 $14.00 \%$ 이하로 건조 가 진행되지 않는다고 보고한 바 있다.

\section{건조버섯의 수축률}

식물의 조직은 팽압현상에 의하여 장력과 탄성을 유지하 고 있으나, 가열처리하면 세포벽이 붕괴되어 조직이 위조 되고 수축하게 되며 복원성을 잃게 된다(22). 그러므로 수축 률은 피건조물의 이화학적 품질특성의 중요한 항목 중 하나 이다. 자연건조 및 열풍건조한 약용버섯과 식용버섯의 장 방형 및 정방형절편의 수축률을 조사한 결과를 Fig. 3, 4에 나타내었다. 자연건조구의 수축률은 영지버섯 3.83 4.57\%, 상황버섯 4.34 4.88\%, 새송이버섯 $63.98 \sim 73.08 \%$, 표고버 섯 43.59 57.00\%이었으며, 열풍건조구는 영지버섯 7.31 10.83 , 상황버섯 6.15 12.98, 새송이버섯 12.17 41.79\%, 표 고버섯 10.64 33.02\%로 나타났다. 약용버섯은 자연건조구 가 수축률이 적어서 원형을 보다 잘 유지되었으나 식용버섯 은 수축률이 큰 자연건조구에 비하여 열풍건조구가 보다 더 원형이 잘 유지되었다. 절단 형태에 따른 유의적 차이는 약용버섯에서는 나타나지 않았으나, 식용버섯은 장방형절 편 보다 정방형절편의 수축률이 유의적으로 낮게 나타났다 $(\mathrm{p}<0.05)$. 정방형절편은 장방형에 비하여 건조표면적이 고 르고 넓어서 건조속도가 신속하기 때문인 것으로 사료된 다. 모든 건조구에서 식용버섯은 약용버섯에 비해 비교적 으로 수축률이 큰 것으로 나타났으며, 약용버섯은 건조온 도가 낮을수록, 식용버섯은 건조온도가 높을수록 낮은 수 축률을 보였다. 이는 건조온도가 증가함에 따라 영지버섯 (23), 마른진흙버섯(24)의 수축률이 크다는 보고와 유사한 결과이다. 식용버섯은 약용버섯과는 다르게 높은 건조 온 도에서 단 시간에 내부 수분이 표면으로 이동되면서 건조가 신속하게 일어나고 그만큼 가열 노출 시간이 적기 때문에 수축률이 감소하게 된다(25).
색도 변화

색도는 식품의 이화학적인 품질을 외관적으로 판단하는 기준이 되며 건조 제품의 색도는 품질 지표가 되며, 저장성 과도 밀접한 관련이 있다(26). 약용버섯과 식용버섯의 장방 형절편에 대하여 건조 전후의 색도를 Hunter 색차계를 이용 하여 측정한 결과는 Table 2 와 같다. 명도를 나타내는 L값은 건조가 진행됨에 따라 모든 건조구에서 감소하는 경향을

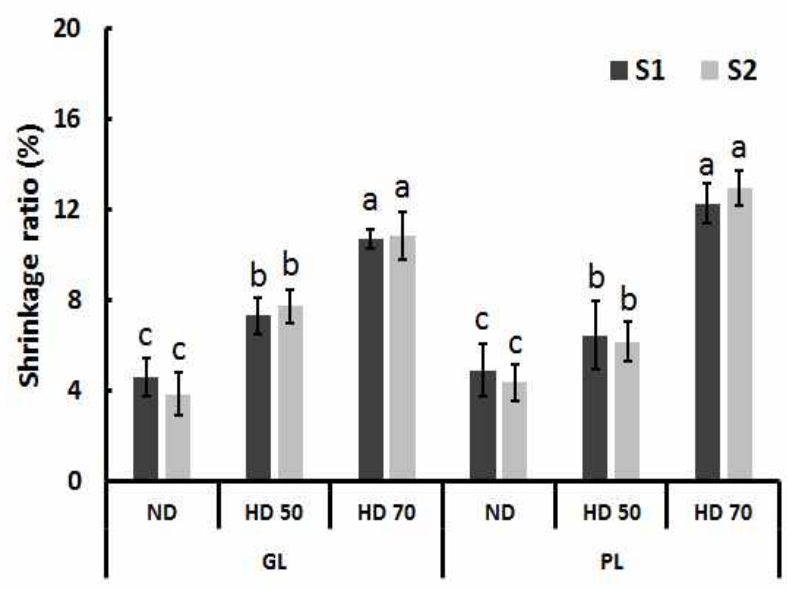

Fig. 3. Shrinkage ratios of the dried medicinal mushrooms depending on the drying conditions.

GL, Ganoderma lucidum, PL, Phellinus linteus. ND, natural drying, HD50, hot-air drying at $50^{\circ} \mathrm{C} ; \mathrm{HD} 70$, hot-air drying at $70^{\circ} \mathrm{C}$. S1, rectangular shape slice $(1 \mathrm{~cm}) ; \mathrm{S} 2$, square shape slice $(1 \times 1 \mathrm{~cm})$. Means with different superscript above the bar are significantly different $(\mathrm{p}<0.05)$ by Duncans's multiple range test.

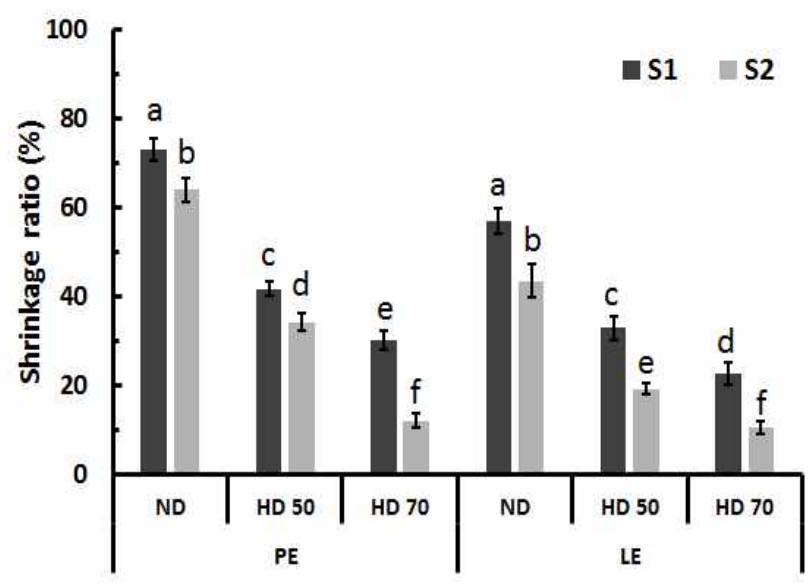

Fig. 4. The shrinkage ratios of the dried edible mushrooms depending on the drying conditions.

$\mathrm{PE}$, Pleurotus eryngii, LE, Lentinus edodes. ND, natural drying; HD50, hot-air drying at $50^{\circ} \mathrm{C} ; \mathrm{HD} 70$, hot-air drying at $70^{\circ} \mathrm{C}$. S1, rectangular shape slice $(1 \mathrm{~cm}) ; \mathrm{S} 2$, square shape slice $(1 \times 1 \mathrm{~cm})$. Means with different superscript above the bar are significantly different $(\mathrm{p}<0.05)$ by Duncans's multiple range test.

보였다. 영지버섯은 자연건조구에서, 상황버섯은 $50^{\circ} \mathrm{C}$ 열 풍건조구에서, 새송이버섯과 표고버섯은 $70^{\circ} \mathrm{C}$ 열풍건조구 에서 가장 높은 $\mathrm{L}$ 값을 나타내었다. 적색도를 나타내는 $\mathrm{a}$ 값 은 영지버섯은 자연 및 열풍건조구에서 유의적으로 감소하 
였으나 다른 버섯에서는 거의 변화가 없었다. Tian 등(27)은 본 연구 결과와 유사하게 표고버섯을 열풍건조 하였을 때 적색도의 변화가 적었다고 보고한 바 있다. 황색도를 나타 내는 b값은 영지버섯에서는 건조 후 감소하였고 상황버섯 에서는 증가하였다. 이는 건조가 진행됨에 따라 상황버섯 의 고유한 황색이 짙어지는 것으로 보아지며, 음건 보다는 열풍건조에서 $\mathrm{b}$ 값이 증가한다는 Jo 등(8)의 보고와 유사하 였다. 식용버섯의 $\mathrm{b}$ 값은 건조 전에 비해 모든 건조구에서 증가하였으며 열풍건조구에 비해 자연건조구가 높았다 $(\mathrm{p}<0.05)$. 갈변 정도를 나타내는 $\Delta \mathrm{E}$ 값은 약용버섯은 자연건 조구보다 열풍건조구가 높았으며, 식용버섯은 $\mathrm{b}$ 값과 마찬 가지로 자연건조구에서 높았다. 자연건조구가 열풍건조구 에 비하여 건조시간이 길기 때문에 공기와의 접촉에 의한 산화적 갈변이 많이 발생하고, 약용버섯에 비하여 수분함 량이 높고 색상이 밝은 식용버섯이 이러한 산화적 갈변이 보다 많이 일어나기 때문으로 생각된다(28).

Table 2. Hunter's color values of the medicinal and edible mushrooms depending on the drying conditions

\begin{tabular}{|c|c|c|c|c|c|}
\hline Sample ${ }^{1)}$ & $\begin{array}{l}\text { Drying } \\
\text { method }\end{array}$ & $\mathrm{L}$ & a & $\mathrm{b}$ & $\Delta \mathrm{E}$ \\
\hline \multirow{4}{*}{ GL } & $\mathrm{BD}$ & $38.75 \pm 0.45^{\mathrm{a} 4)}$ & $24.94 \pm 1.18^{\mathrm{a}}$ & $22.71 \pm 1.10^{\mathrm{a}}$ & $0.00 \pm 0.00^{c}$ \\
\hline & ND-S1 ${ }^{3)}$ & $37.83 \pm 0.69^{b}$ & $22.19 \pm 0.85^{b}$ & $17.44 \pm 1.10^{b}$ & $6.13 \pm 1.44^{b}$ \\
\hline & HD50-S1 & $37.09 \pm 0.70^{c}$ & $19.88 \pm 0.98^{c}$ & $15.01 \pm 1.43^{\mathrm{c}}$ & $9.72 \pm 2.15^{\mathrm{a}}$ \\
\hline & HD70-S1 & $33.09 \pm 1.14^{\mathrm{d}}$ & $20.41 \pm 1.11^{\mathrm{c}}$ & $15.36 \pm 1.07^{\mathrm{c}}$ & $10.45 \pm 2.19^{\mathrm{a}}$ \\
\hline \multirow{4}{*}{ PL } & $\mathrm{BD}$ & $22.7 \pm 0.98^{\mathrm{d}}$ & $6.94 \pm 0.85^{\mathrm{b}}$ & $20.47 \pm 2.07^{\mathrm{c}}$ & $0.00 \pm 0.00^{\mathrm{d}}$ \\
\hline & ND-S1 & $24.17 \pm 1.14^{\mathrm{c}}$ & $7.36 \pm 0.56^{b}$ & $19.13 \pm 1.35^{\mathrm{d}}$ & $3.35 \pm 1.23^{\mathrm{c}}$ \\
\hline & HD50-S1 & $30.14 \pm 1.45^{\mathrm{b}}$ & $6.94 \pm 1.16^{b}$ & $24.93 \pm 2.04^{\mathrm{b}}$ & $9.11 \pm 2.88^{\mathrm{b}}$ \\
\hline & HD70-S1 & $32.52 \pm 2.04^{\mathrm{a}}$ & $8.51 \pm 0.68^{\mathrm{a}}$ & $26.24 \pm 2.21^{\mathrm{a}}$ & $11.84 \pm 3.77^{\mathrm{a}}$ \\
\hline \multirow{4}{*}{$\mathrm{PE}$} & $\mathrm{BD}$ & $94.75 \pm 0.23^{\mathrm{a}}$ & $-0.62 \pm 0.04^{c}$ & $8.78 \pm 0.27^{c}$ & $0.00 \pm 0.00^{c}$ \\
\hline & ND-S1 & $78.75 \pm 1.01^{\mathrm{c}}$ & $0.50 \pm 0.22^{\mathrm{a}}$ & $26.21 \pm 1.01^{\mathrm{a}}$ & $23.69 \pm 1.29^{\mathrm{a}}$ \\
\hline & HD50-S1 & $85.48 \pm 1.66^{b}$ & $-0.74 \pm 0.45^{\mathrm{c}}$ & $19.66 \pm 1.4^{\mathrm{b}}$ & $14.38 \pm 1.66^{b}$ \\
\hline & HD70-S1 & $84.96 \pm 2.01^{b}$ & $0.11 \pm 0.16^{b}$ & $19.41 \pm 1.01^{b}$ & $14.52 \pm 1.89^{b}$ \\
\hline \multirow{4}{*}{ LE } & $\mathrm{BD}$ & $90.69 \pm 1.30^{\mathrm{a}}$ & $1.02 \pm 0.41^{b}$ & $10.08 \pm 1.32^{\mathrm{d}}$ & $0.00 \pm 0.00^{d}$ \\
\hline & ND-S1 & $77.51 \pm 1.55^{\mathrm{d}}$ & $1.90 \pm 0.25^{\mathrm{a}}$ & $27.17 \pm 0.84^{\mathrm{a}}$ & $20.31 \pm 2.03^{\mathrm{a}}$ \\
\hline & HD50-S1 & $83.34 \pm 2.08^{\mathrm{b}}$ & $0.93 \pm 0.68^{b}$ & $18.67 \pm 0.98^{c}$ & $11.43 \pm 2.60^{c}$ \\
\hline & HD70-S1 & $80.88 \pm 0.87^{\mathrm{c}}$ & $2.02 \pm 0.44^{\mathrm{a}}$ & $19.55 \pm 1.28^{\mathrm{b}}$ & $14.39 \pm 1.99^{b}$ \\
\hline
\end{tabular}

${ }^{1)} \mathrm{GL}$, Ganoderma lucidum, PL, Phellinus linteus, PE, Pleurotus eryngï, LE, Lentinus edodes.

${ }^{2)} \mathrm{BD}$, before drying; ND, natural drying; HD50, hot-air drying at 50; $\mathrm{HD} 70$, hot air drying at 70 .

${ }^{3)} \mathrm{S} 1$, rectangular shape slice $(1 \mathrm{~cm})$.

3)ad means with different letters within the column are significantly different $(\mathrm{p}<0.05)$.

\section{건조버섯의 재수화율}

재수화성은 건조된 시료가 수분을 다시 흡수하여 본래의 품질 특성을 회복하는 정도를 말하며 조직의 변화가 비가역 적이므로, 건조 방법과 온도에 따라서 영향을 받게 된다.
장방형절편과 정방형절편의 약용버섯 및 식용버섯 시료의 재수화성을 측정한 결과는 Table 3 과 같다. 절단 형태에 따른 재수화율은 모든 건조구에 있어서 장방형절편 보다 정방형절편이 높은 경향을 보였다. 식용버섯은 열풍건조구 에 비해 자연건조구에서 높은 재수화율을 나타내었으며 $70^{\circ} \mathrm{C}$ 열풍건조구가 $50^{\circ} \mathrm{C}$ 보다 낮았다 $(\mathrm{p}<0.05)$. 이는 열풍건 조 온도가 증가함에 따라 표고버섯의 재수화율이 낮아진다 는 Park 등(29)의 보고와 유사하였다. 약용버섯은 자연건조 구 보다 열풍건조구에서 재수화율이 높았으며, $50^{\circ} \mathrm{C}$ 열풍 건조구가 $70^{\circ} \mathrm{C}$ 보다 높았다. 최종수분함량이 $70^{\circ} \mathrm{C}$ 열풍건조 구 보다 $50^{\circ} \mathrm{C}$ 열풍건조구가 높은 결과(Table 1)임에도 불구 하고 재수화율이 높게 나타난 것은 $70^{\circ} \mathrm{C}$ 열풍건조구에 비하 여 $50^{\circ} \mathrm{C}$ 열풍건조구가 가열에 의한 버섯조직의 손상이 비교 적 적었기 때문으로 생각된다.

Table 3. Rehydration ratios of the medicinal and edible mushrooms depending on the drying conditions

(unit: \%)

\begin{tabular}{|c|c|c|c|}
\hline \multirow{2}{*}{ Sample ${ }^{1)}$} & \multirow{2}{*}{$\begin{array}{l}\text { Drying } \\
\text { method }^{2}\end{array}$} & \multicolumn{2}{|c|}{ Rehydration ratio } \\
\hline & & $\mathrm{S1}^{3)}$ & S2 \\
\hline \multirow{3}{*}{ GL } & $\mathrm{ND}$ & $198.67 \pm 1.40^{(4) A 5)}$ & $200.85 \pm 8.17^{\mathrm{bA}}$ \\
\hline & HD50 & $254.71 \pm 5.66^{\mathrm{aA}}$ & $263.10 \pm 8.74^{a \mathrm{~A}}$ \\
\hline & $\mathrm{HD} 70$ & $228.16 \pm 3.47^{\mathrm{bB}}$ & $252.36 \pm 10.79^{\mathrm{aA}}$ \\
\hline \multirow{3}{*}{ PL } & ND & $137.95 \pm 15.83^{\mathrm{bB}}$ & $197.39 \pm 7.13^{\mathrm{aA}}$ \\
\hline & HD50 & $179.88 \pm 11.47^{\mathrm{aA}}$ & $195.95 \pm 11.33^{\mathrm{aA}}$ \\
\hline & $\mathrm{HD} 70$ & $141.61 \pm 7.99^{6 B}$ & $171.70 \pm 8.34^{\mathrm{bA}}$ \\
\hline \multirow{3}{*}{$\mathrm{PE}$} & $\mathrm{ND}$ & $319.04 \pm 9.03^{\mathrm{aB}}$ & $345.23 \pm 12.81^{\mathrm{aA}}$ \\
\hline & HD50 & $231.08 \pm 6.78^{b B}$ & $273.44 \pm 10.65^{\mathrm{bA}}$ \\
\hline & $\mathrm{HD} 70$ & $158.23 \pm 3.65^{\mathrm{cB}}$ & $211.93 \pm 8.04^{\mathrm{cA}}$ \\
\hline \multirow{3}{*}{ LE } & $\mathrm{ND}$ & $558.29 \pm 13.21^{a \mathrm{~B}}$ & $940.00 \pm 12.39^{\mathrm{aA}}$ \\
\hline & HD50 & $506.32 \pm 10.46^{\mathrm{bB}}$ & $524.21 \pm 2.00^{\mathrm{bA}}$ \\
\hline & $\mathrm{HD} 70$ & $331.23 \pm 15.76^{\mathrm{cA}}$ & $335.05 \pm 10.91^{\mathrm{cA}}$ \\
\hline
\end{tabular}

${ }^{1)} \mathrm{GL}$, Ganoderma lucidum, PL, Phellinus linteus, PE, Pleurotus eryngï, LE, Lentinus edodes.

${ }^{2} \mathrm{ND}$, natural drying; $\mathrm{HD} 50$, hot-air drying at $50^{\circ} \mathrm{C} ; \mathrm{H} 70$, hot-air drying at $70^{\circ} \mathrm{C}$. ${ }^{3)} \mathrm{S} 1$, rectangular shape slice $(1 \mathrm{~cm})$; S2, square shape slice $(1 \times 1 \mathrm{~cm})$.

4)ac means with different letters within the column are significantly different $(p<0.05)$.

${ }^{5 A-B}$ means with different letters within the row are significantly different $(\mathrm{p}<0.05)$.

\section{요 약}

약용버섯(영지버섯, 상황버섯)과 식용버섯(새송이버섯, 표고버섯)을 장방형 $(1 \mathrm{~cm})$ 과 정방형 $(1 \times 1 \mathrm{~cm})$ 으로 절단하 여 자연건조와 열풍건조 $\left(50^{\circ} \mathrm{C}, 70^{\circ} \mathrm{C}\right)$ 하면서 건조특성을 조 사하고 건조 시료의 수축률, 색도 및 재수화성을 조사하였 다. 건조 전의 초기수분함량은 약용버섯에 비해 식용버섯 이 높았으며, 건조 후 최종수분함량은 약용버섯이 높았다. 
건조속도는 $70^{\circ} \mathrm{C}$ 열풍건조가 가장 빨랐으며, 장방형절편 보다 정방형절편에서 건조 속도가 빨랐다 $(\mathrm{p}<0.05)$. 수축률 은 약용버섯은 $50^{\circ} \mathrm{C}$ 열풍건조, 식용버섯은 $70^{\circ} \mathrm{C}$ 열풍건조가 가장 작았으며 정방형 절편이 장방형에 비해 낮았다 $(\mathrm{p}<0.05)$. Hunter 색차계로 색도 값을 조사한 결과, 약용버섯 은 자연건조구, 식용버섯은 열풍건조구가 색도 변화가 작 았으며, 갈변도를 나타내는 $\Delta \mathrm{E}$ 값도 적었다 $(\mathrm{p}<0.05)$. 재수화 율은 약용버섯은 $50^{\circ} \mathrm{C}$ 열풍건조구, 식용버섯은 자연건조구 에서 높게 나타났다( $<<0.05) .50^{\circ} \mathrm{C}$ 열풍건조가 비교적 건조 시간이 짧으며, 수축률이 낮고, 갈변이 적게 일어나며, 재수 화율이 높아서 효율적인 것으로 사료된다.

\section{감사의 글}

본 연구는 농림축산식품부 고부가가치 식품기술개발사 업에 의해 이루어진 것으로 연구비 지원에 감사드립니다.

\section{References}

1. Choi SJ, Lee YS, Kim JK, Lim SS (2010) Physiological activities of extract from edible mushrooms. J Korean Soc Food Sci Nutr, 39, 1087-1096

2. Bano Z, Rajarathnam S (1988) Pleurotus mushrooms. Part П. Chemical composition, nutritional value post-harvest physiology, preservation, and role as human food. Crit Rev Food Sci Nutr, 27, 87-158

3. Moradali MF, Mostafavi H, Ghods S, Hedjaroude GA (2007) Immunomodulating and anticancer agents in the realm of macromycetes fungi (macrofungi). Int Immunopharmaco, 7, 701-724

4. Lee SC, Ju YC, Kim JH (2007) Effect of far-infrared irradiation on the antioxidant activity of extracts from Phellinus igniarius and Ganoderma lucidum. Korean J Food Sci Technol, 39, 386-389

5. Kang TS, Kang MS, Sung JM, Kang AS, Shon HR, Lee SY (2001) Effect of Pleurotus eryngii on the blood glucose and cholesterol in diabetic rats. Korean J Mycol, 29, 86-90

6. Qi Y, Zhao X, Lim YI, Park KY (2013) Antioxidant and anticancer effects of edible and medicinal mushrooms. Korean J Soc Food Sci Nutr, 42, 655-662

7. Kim, BS, Nahmgung B, Kim OW, Kim DC (1995) Freshness keeping of shiitake mushroom by vacuum cooling. Korean J Food Sci Technol, 27, 852-859

8. Jo WS, Park SD, Park SC, Chang ZQ, Seo GS, Uhm
JY, Jung HY (2009) Changes in quality of Phellinus gilvus mushroom by different drying methods. Mycoscience, 50, 70-73

9. Addo A, Bart-Plange A, Boakye DM (2009) Drying characteristics of cap and stem of mushroom. Ghana J Sci Technol, 29

10. Shong SK, Koh HK, Lee JH (1994) Drying characteristics of mushroom. J Biosystems Eng, 19, 112-123

11. Swasdisevi T, Devahastin S, Sa-Adchom P, Soponronnarit S (2009) Mathematical modeling of combined far-infrared and vacuum drying banana slice. J Food Eng, 92, 100-106

12. Darvishi H, Najafi G, Hosainpour A, Khodaei J, Aazdbakht M (2013) Far-Infrared Drying Characteristics of Mushroom Slices. Chem Prod Process Model, 8, $107-117$

13. Guo XH, Xia CY, Tan YR, Chen L, Ming J (2014) Mathematical modeling and effect of various hot-air drying on mushroom (Lentinus edodes). J Integrative Agric, 13, 207-216

14. Ha YS, Park JW, Lee JH (2001) Physical characteristics of mushroom (Agaricus bisporus) as influenced by different drying methods. Korean J Food Sci Technol, $33,245-251$

15. Woo KS, Jeong HS, Lee HB, Choi WS (2004) Changes in rheological properties of neungee (Sarcodon aspratus) during dehydration. Korean J Soc Food Sci Nutr, 33, 1230-1236

16. AOAC (1996) Official Methods of Analysis. 15th ed, Association of Official Analytical Chemists, Washington DC, $p$ 210-219

17. Jeong DW, Park YK, Nam SS, Han SK (2015) Effect of hot-air drying temperature on nutritional components and rehydration rate of sweetpotato leaves. Koran J Food Preserv, 22, 498-504

18. Smith JE, Rowan NJ, Sullivan R (2002) Medicinal mushrooms a rapidly developing area of biotechnology for cancer therapy and other bioactivities. Biotechnol Lett, 24, 1839-1845

19. Kim DH, Choi HJ, Jo WS, Moon KD (2012) Quality characteristics of Pleurotus eryngii cultivated with different wavelength of LED ligths. Korean J Food Preserv, 19, 354-360

20. Krokida, MK, Karathanos VT, Maroulis ZB, MarinosKouris D (2003) Drying kinetics of some vegetables. J Food Eng, 59, 391-403

21. Yoo BY, Jang MS, Eun JB (2003) Physicochemical characteristics and optimal drying temperature condition 
of agaricus (Agaricus Blaze1) mushroom. Korean J Food Preserv, 10, 476-481

22. Ratti C (1994) Shrinkage during drying of foodstuffs. J Food Eng, 23, 91-105

23. Ha TM, Chi JH, Ju YC, Lee HG (1995) Established test of Ganoderma lucidum drying technology. Mushroom Reseach Institute Gyeonggi Province ARES, REM0031620, 691-694

24. Jo WS (2006) Drying method after harvest of Phellinus. (2006) J mushrooms, 94, 70-76

25. Brasiello A, Adiletta G, Russo P, Crescitelli S, Albanese D, Di Matteo M (2013) Mathematical modeling of eggplant drying shrinkage effect. J Food Eng, 114, 99-105

26. Sun SH, Kim SJ, Kim GC, Kim HR, Yoon KS (2011) Changes in quality characteristics of fresh-cut produce during refrigerated storage. Korean J Food Sci Technol, 43, 495-503

27. Tian Y, Zhao Y, Huang J, Zeng H, Zheng B (2016) Effects of different drying methods on the product quality and volatile compounds of whole shiitake mushrooms. Food Chem, 197, 714-722

28. Jee, JH, Lee HD, Chung, SK, Choi JU (1999) Changes in color value and chemical components of hoelen by various drying methods. Korean J Food Sci Technol, 31, 575-580

29. Jin TY, Oh DH, Eun JB (2006) Change of physicochemical characteristics and functional components in the raw materials of Saengsik, uncooked food by drying methods. Korean J Food Sci Technol, 38, 188-196 